\title{
A Note on Dante's Missing Musaeus (Inferno IV. 140-41)
}

\section{Robert Hollander}

In a tradition which perhaps begins with Aristotle (Metaphysics I. iv. 83 - cited by Padoan $)^{1}$ and continues into the Christian Middle Ages by agency of such important texts as Augustine's De civitate Dei (XVIII. xiv. xxxvii — cited by Mazzoni) ${ }^{2}$ Orpheus, Musaeus, and Linus are accounted the first theologi poetae. (The concept is central to the debate over the theological aspiration of poetry; for discussion see, inter alios, Curzius.) In this tradition they are usually, if not always, mentioned together - often enough in a single breath that, while a gesture toward one of them might not always automatically trigger thoughts of the other two, it is rare to find two of them mentioned without the third (for "orthodox" references to the three "theological poets" see Boccaccio, ${ }^{3}$ as well as the Genealogia deorum, XIV. viii, where they are thrice referred to). Yet that is precisely the case in Inferno IV. 140-41:

... e vidi Orfeo,

Tulio e Lino e Seneca morale.

The verse has caused its share of difficulty, particularly with respect to the name "Lino," which has been variously deformed, as Mazzoni documents. Following. Moore, ${ }^{4}$ he has shown authoritatively that "Lino" is the valid reading. And as Mazzoni ${ }^{5}$ goes on to demonstrate, the Aristotelian/Augustinian tripartite commonplace was surely known to Dante at least from Thomas's commentary to the Metaphysics, which in several passages refers to "Orpheus, Museus et Linus" (e.g., I lect. iv. 83; XII lect. vi. 2502). Mazzoni concludes his examination of the problem as follows: "resta semmai da chiedersi il perché dell'esclusione dal numero di Museo: domanda cui non sappiamo rispondere. ${ }^{16}$ The problem 
may be stated as follows. If we may be certain that Dante here refers to Orpheus and to Linus as theologi poetae, how may we explain the absence of reference to Musaeus? It is of course possible that the "binary weaving" of the exempla here (referred to by Kraus), ${ }^{7}$ two Greek poet-theologians balanced by two Roman philosophers - Cicero and Seneca, simply forced the exclusion of one of the three; if such was the case, our puzzlement is of our own devising. On the other hand, and to agree with Mazzoni, it seems more logical to assume that Dante would have expected us to be watching to see the third familiar name fall into place and thus that there is a reason which may account for the suppression of Musaeus's name here. Without further delay I offer the following experimental solution to the problem.

There is a single case known to me of a similar reference to these two alone of the triumvirate. While it has been noted by Mazzoni, ${ }^{8}$ Kraux, ${ }^{9}$ and Padoan, ${ }^{10}$ none of them - nor anyone else, to my knowledge - has studied the context of this passage in order to see if it might help to explain Dante's similar omission of Musaeus. Virgil's fourth Eclogue contains the following verses (53-57):

o mihi tum longae maneat pars ultima vitae, spiritus et quantum sat erit tua dicere facta: non me carminibus vincet nec Thracius Orpheus, nec Linus, huic mater quamvis atque huic pater adsit, Orphei Calliopea, Lino formosus Apollo.

(O then may a long life's final days remain for me And breath sufficient to chronicle your deeds.

None would defeat me in song, not Thracian Orpheus,

Not Linus, though one have his mother's, one his father's aid, Orpheus Calliope's, Linus beautiful Apollo's. - Tr. A. J. Boyle)

If Dante expected us to wonder what had happened to Musaeus's name, did he not hope we might direct our attention to this text? We know with what care Dante inspected the Eclogue, hardly requiring the presence of his vernacularization of verses 5-7 in Purgatorio XXII. 70-72, to assure ourselves that he, like any number of other Christian apologists of his age, was a close reader of this most inviting and troubling of pagan texts. For Dante, Virgil himself meant to speak only of Astraea (see Monarchia I. xi. 1) and consequently not of the Christ child; yet Statius, in Dante's fiction, read the text - as some others did in fact also do - as a prophecy of the Christ. Dante's presentation of Virgil as inadequate reader of his own text - a view of the matter promoted by 
Statius's salvation by virtue of his better reading and by Virgil's damnation - may also lie behind Dante's citation of Virgil's Orpheus and Linus. ${ }^{11}$ For what had Virgil proposed? If he be allowed to live long enough (and if the golden age return - Virgil is indeed carefully hypothetical), then he will sing the deeds of this child in ways which will outdo even Orpheus and Linus. But where do we find Virgil in Dante's afterworld? In the same station of eternity as that occupied by these very two theologi poetae. By referring only to them. by omitting the expected name of Musaeus, Dante, it seems to me, has first put this text into our minds and then invited us to turn the half-uttered vaunt which it contains against its maker. (If, as I believe, and as a graduate student at Princeton, Mark Epstein, indeed suggested in 1981, several details of the presentation of Sordello in Purgatorio VI. 58-68, are meant to reflect Virgil's similar presentation of Musaeus in Aeneid VI. 667-78 - each poet acting as subordinate guide to a better place situated on a slope above, then we would have still stronger reasons to believe that the lack of reference to Musaeus in this passage is both intentional and meaningful.) It is Statius, reading the Eclogue in a better light, who will "outdo" Orpheus and Linus, and not Virgil.

A similar concern for the way in which Virgil nearly found his way to heaven but ultimately failed has already made itself felt in this canto. And one of its most cited loci, read in a fresh light, offers still further corroboration. In the spring of 1982 a singular interpretation of this familiar text suggested itself to Elizabeth Statmore, then studying with me at Princeton:

“Onorate l'altissimo poeta;

l'ombra sua torna, ch'era dipartita." (Inf. IV. 80-81)

It is, as Mazzoni, ${ }^{12}$ following D'Ovidio, argues, surely Homer who speaks here. The honorific solemnity of the moment may have held us back from seeing, behind the generous praise lavished upon Virgil, a darker side to Homer's compliment. It was only thirty verses earlier that Dante had asked Virgil about the harrowing of hell by the true nova progenies (IV 49-51). Benvenuto's ascription of malice aforethought to the questioner is worth repeating, for we tend to treat the query, referred to by Dante himself as "il mio parlar coverto" (thus indicating a covert purpose to the question, however we choose to interpret it), as being more neutral than it was probably meant to be perceived: ". . . tacite dixeram: vos magni philosophi et poetae, quid profecit 
vobis ad salutem vestra sapientia magna sine fede? Certe nihil: quia antiqui patres qui simpliciter et fideliter crediderunt, extracti sunt de carcere isto, ubi vos estis perpetuo permansuri" (". . . as though my words had hidden the thought 'you great philosophers and poets, your great wisdom, what good did it, without faith, accomplish for your salvation? Certainly none at all, for even the ancient patriarchs, in their simple, faithful credence, were drawn up out of this prison, in which place you are to remain for ever and ever"'). Virgil and the rest of the souls in Limbo have witnessed not only the Harrowing but, we subsequently infer (Purgatorio X. 73-76; Paradiso XX. 44-48), the later ascent to earth (and thence to heaven) of Trajan. What did they think when they saw Virgil leaving Limbo in the company of Beatrice? As Iannucci has demonstrated more fully than anyone, ${ }^{13}$ Beatrice, in her descent to the underworld, is described in ways that are calculated to put us in mind of Christ's descent. If Dante expected us to put that earlier great event alongside of this new miracle, did he not also expect us to think it would have been on the minds of those who witnessed so similar a miracle? Might they not have assumed - and quite naturally so - that Virgil, like Cato, Ripheus, and the other latter-day saint, Trajan, was destined for eternal bliss? If that is what they thought, Homer's salutation mirrors their reconfirmation in their knowledge that Virgil was, after all, only one of them. And if at the end of the canto he departs with Dante, he himself will always know his place, as he makes plain when expresses his hopes for Statius (Purgatorio XXI. 16-18):

"Nel beato concilio

ti ponga in pace la verace corte

che me rilega ne l'etterno essilio."

He shares this exile not only with the regulati poetae of the bella scola, but also with the two theologi poetae, Orpheus and Linus, whom he had thought he might surpass.

While I am aware that "proof" is beyond such demonstrations, I think that the importance of the fourth Eclogue to Dante, the formulaic nature of the identification of Orpheus, Musaeus, and Linus as theologi poetae, and Dante's sense of Virgil's tragic failure to see the light all combine to make this reading of a puzzling detail a plausible one. 


\section{NOTES}

1 G. Padoan, "Orfeo," in Enciclopedia Dantesca, IV (1973), p. 192.

2 F. Mazzoni, Saggio di un nuovo commento alla "Commedia": il Canto IV dell' "Inferno," in Studi Danteschi, XLII (1973), 29-206.

3 G. Boccaccio, Esposizioni sopra la Comedia di Dante, a cura di Giorgio Padoan, vol. VI of Tutte le opere di Giozanni Boccaccio, a cura di Vittore Branca (Milano: Mondadori, 1965).

4 E. Moore, Studies in Dante. First Series (Oxford: Clarendon, 1969 [1896]), p. 192.

5 F. Mazzoni, p. 197.

6 Ibid.

7 C. Kraus, "Lino," in Enciclopedia Dantesca, IV (1973), pp. 664-65.

8 F. Mazzoni, p. 197.

9 C. Kraus, cit.

10 G. Padoan, cit.

11 For my own views on this important and difficult subject see my $I l$ Virgilio dantesco: tragedia nella "Commedia" (Firenze: Olschki, 1983).

12 F. Mazzoni, p. 128.

13 A.A. Iannucci, "Beatrice in Limbo: A Metaphoric Harrowing of Hell," in Dante Studies, XCVII (1979), 23-45. 